\title{
Factors Affecting Adoption of Facebook: An Exploratory Study of the LIS Community Perspective
}

\section{Noa Aharony}

This study seeks to investigate whether information professionals, as well as LIS students, are ready to assimilate Facebook in their work and educational environments. The study uses the Technology Acceptance Model (TAM) as well as some characteristics of the "Big Five" model of personality as a theoretical base from which to predict factors that may influence the adoption of Facebook by information professionals as well as by LIS students. Findings reveal that the TAM, as well as other personal characteristics, significantly predict the likelihood of Facebook use and highlight the importance of individual characteristics when considering technology acceptance.

\section{Introduction}

\section{Social Networks}

Facebook, the social networking site (SNS), has gained increasing popularity worldwide and, as of February 2013, has more than one billion active users. Boyd and Ellison note that SNSs help people keep in touch with past offline contacts, as well as create new contacts with those who share common likes and interests. ${ }^{1}$ Social networking sites have been defined as, "Web-based services that allow individuals to (1) construct a public or semi-public profile within a bounded system, (2) articulate a list of other users with whom they share a connection, and (3) view and traverse their list of connections." 2 Suki, Ramayah, and Ly assert that SNSs are perceived as private spaces where young people are just "hanging out" and playing with notions of identity and belonging. Facebook presents features such as walls, status updates, photos, news feeds, tagging, marketplaces, instant messaging, videos, and the like. ${ }^{3}$ Urista, Dong, and Day claim that the popularity of Facebook is associated with the fact that it is a relatively open and transparent platform, enabling people to gather personal information about other users. ${ }^{4}$ According to a Pew Research Center report, 67 percent of Americans use Facebook, 72 percent of whom are women, and 86 percent are between 19 and 28 years of age. However, some interesting and surprising facts are that 61 percent of current users say that they have voluntarily taken a break from Facebook for a period of several weeks, and 20 percent noted that they do not use Facebook any longer. ${ }^{5}$

Noa Aharony is a Senior Lecturer at the Information Science Department in Bar-Ilan University; e-mail: noa.aharony@biu.ac.il. (C2014 Noa Aharony, Attribution-NonCommercial (http://creativecommons.org/ licenses/by-nc/3.0/) CC BY-NC 


\section{Facebook in the Library Arena}

First articles dealing with Facebook use in the library appeared in 2007. Several researchers noted that libraries should use Facebook to market their services to be where users are and to make themselves accessible to patrons. ${ }^{6}$ However, others claim that Facebook did not serve any academic purposes. ${ }^{7}$ Those librarians who were in favor of using Facebook in the library reported that, when using Facebook, 29 percent of reference questions came through Facebook. ${ }^{8}$ Others stated that students sent queries to the "wall," and Alcock described a project where the University of Wolverhampton in the United Kingdom established a Facebook page with links to the library website, RSS to librarians' blogs, and search applications. ${ }^{9}$ Further, Kim Phillips found that library Facebook pages serve as a channel of information for libraries and that librarians try to establish rapport with students through Facebook. Hendrix and et al. suggested the following activities that library can do through Facebook: announcements and marketing, photos, reference services, forums for users, OPAC search, database search, employee announcements, and employee communication. ${ }^{10} \mathrm{Chu}$ and Meulemans added that Facebook can be used for information literacy instruction. ${ }^{11}$ Moreover, Garcia-Milian, Norton, and Tennant found positive correlations between number of library fans and number of tabs, photos, events, and wall posts on Facebook. They emphasized that libraries that posted videos had more fans than libraries without them. ${ }^{12}$ However, librarians should be aware that, if they decide to use Facebook in their libraries, they should update it at least once a week. ${ }^{13}$

Thus, it will be interesting to explore what factors influence information professionals', as well as Library and Information Science (LIS) students', choices when adopting new technologies such as Facebook for work purposes in Israel. It should be mentioned that the situation of the libraries in Israel is quite similar to libraries' situation in North America. There are budget problems, and, as a result, more and more library jobs are cut. In addition, librarians report that fewer users use libraries because they think they can find everything via Google. ${ }^{14}$ Hence, librarians in all sorts of libraries should work very hard to present their added value. For example: public libraries are changing their policy and trying to reinvent themselves to attract users by suggesting leisure activities such as lectures, courses, and different activities to children. ${ }^{15}$ Further, most of the public and academic libraries have different social media applications on their webpage. The most common Web 2.0 tools that are presented on the library websites are these: Facebook, blogs, wikis, RSS, and Twitter. Librarians understand that their users are in those social sites, thus they should be there too. However, not all these social sites are frequently updated or used, and sometimes they just "decorate" the library homepage.

We can see that the issue of adopting new technologies is a central one, and information professionals as well as LIS students should become accustomed to the fact that most of their present or potential users use Facebook as a major factor in their everyday life. They should therefore master this technology not only for fun or hedonic purposes, but rather as a professional venue. In addition, both sectors should understand that Facebook can serve as a convenient avenue of communication with their colleagues, as well as a platform for professional updates.

This study seeks to investigate whether information professionals, as well as LIS students who are familiar with novel technologies, are ready to assimilate Facebook in their work. Though previous studies ${ }^{16}$ have examined Facebook in the library arena, no one has focused so far on both (that is to say, both information professionals and LIS students) perceptions and use. This research could extend our understanding of the factors that influence both groups' Facebook use and may lead to further inquiry in this field. 
The current study uses the Technology Acceptance Model (TAM), a well-known theory that explains whether or not users will use a particular technology. ${ }^{17}$ In conjunction with the TAM, we propose that the same characteristics of the "Big Five" model of personality can serve as a theoretical base from which to predict factors that may influence the adoption of Facebook by information professionals as well as by LIS students within their work or learning environments. ${ }^{18}$ Seeing that personality traits play a primary role in human beliefs, cognition, and behaviors, we believe that personality will be a crucial factor when dealing with individuals' information technology acceptance. The study will therefore explore the relationship between personality traits, TAM, and Facebook use.

The research questions are these: (a) to what extent does the TAM explain information professionals', as well as LIS students', use of Facebook; (b) to what extent do some characteristics of the "Big Five" model explain information professionals', as well as LIS students', use of Facebook; (c) to what extent do differences in demographic variables such as age explain information professionals' and LIS students' use of Facebook. The remainder of the article is organized as follows: the next section introduces the theoretical foundations and hypotheses developed for the study. Research methods are provided next, followed by findings and discussion. The last section provides theoretical contributions, along with a discussion of some limitations of the findings.

\section{Theoretical Background}

\section{Technology Acceptance Model (TAM)}

The Technology Acceptance Model (TAM) is based on the Theory of Reasoned Action (TRA), which has its roots in social psychology and tries to explain why people engage in consciously intended behaviors. According to TRA, behavior is explained by people's behavioral intentions, attitudes, subjective norms, and beliefs. TRA has been used across different areas. ${ }^{19}$ Davis introduced it into information systems and, elaborating on TRA, suggests a model that predicts intention to use a new technology. Davis $^{20}$ also proposes that the process of accepting information systems encompasses two main constructs: perceived usefulness and perceived ease of use. Perceived usefulness (PU) refers to the belief that the target information technology or system will help users perform their tasks, and perceived ease of use (PEOU) relates to the belief that it would be easy to use the target information technology or system. Various studies found that PEOU, as well as PU, affect use of an information system, and that PU mediates the effect of PEOU on usage. ${ }^{21}$

An important addition to the model is a third construct called perceived enjoyment, referring to the extent to which the activity of using the computer is perceived to be enjoyable..$^{22}$ van der Heijden has discussed hedonic systems, stating that the phrase stems from the word "hedonism," a word suggesting that pleasure or happiness is the sole good in life. ${ }^{23} \mathrm{He}$ distinguishes between hedonic and utilitarian systems by proposing that hedonic systems mean to provide self-fulfilling value to their users and that their value is the degree to which users experience fun when using them. On the other hand, utilitarian systems provide instrumental value to their users, such as increasing task performance while encouraging efficiency. van der Heijden continues the distinction between home and work environments. As the home environment is the natural place for hedonic systems, and the work environment the natural place of utilitarian systems, we can assume that perceived enjoyment will play a more dominant role in home environments. ${ }^{24}$

Just as perceived usefulness is predominant at work, van der Heijden suggests that perceived enjoyment and perceived ease of use are stronger factors in hedonic environments and will influence users' intention to use technology when compared 
to perceived usefulness, since these systems provide self-fulfillment value. ${ }^{25}$ Perceived enjoyment has been included in studies of the WWW and mobile commerce, as well as in investigating computer games, instant messaging, and within social networking sites. ${ }^{26}$ The current study focuses on Facebook, which is usually perceived as a hedonic system, suggesting fun. However, it addresses Facebook from a professional aspect, considering it as a channel that may enhance an information organization's performance and work efficiency. Thus, based on van der Heijden, the current study focuses on PEOU and perceived enjoyment as variables that may predict Facebook use in workplaces. ${ }^{27}$

TAM has been further extended and now includes other factors such as subjective norms, task characteristics, individual and cultural differences, and workplace environmental factors. ${ }^{28}$ It has also been used with a variety of populations, such as students, consumers, older adults, and doctors..$^{29}$ Further, Ma and Liu and Yousafzai et al. conducted meta-analysis studies applying TAM to a variety of technologies, confirming that it may explain why various technologies such as software packages and online services are adopted. ${ }^{30}$

\section{Personal Innovativeness}

A second variable that may affect and predict Facebook use by both information professionals and LIS students is personal innovativeness (PI). PI is a famous variable in innovation diffusion research generally. ${ }^{31}$ Rogers defines innovativeness as the degree to which a person, when compared to others, is early in adopting innovations. ${ }^{32}$ Agarwal and Prasad note that the PI variable is associated with information technology; they suggest that it be defined as the willingness to try out new information technology, adding that people with a higher degree of PI would be more likely to take advantage of new technologies. According to their definition, it is a stable personality characteristic not influenced by various situations. ${ }^{33}$ Several studies that focused on personal innovativeness suggested that innovative people are more likely to adopt new technologies, although they are aware of the high degree of uncertainty that follows adoption. ${ }^{34}$ Other researchers found that innovative people search for intellectually or sensorially stimulating experiences. ${ }^{35}$

\section{The Big Five}

The following section will focus on personality characteristics that might affect information professionals', as well as LIS students', Facebook use. The current research uses some characteristics of the Big Five model, the most accepted model of personality. ${ }^{36}$ The model was examined, and we can assume it represents the best-known personality traits. ${ }^{37}$ The model addresses the following characteristics: extraversion, agreeableness, openness to experience, conscientiousness, and neuroticism. Extraversion is characterized by a person's tendency to seek stimulation in the external world, to be outgoing, talkative, friendly, and socially active. Agreeableness focuses on the degree to which a person maintains positive social relations; these people tend to be friendly and compassionate and to behave in a cooperative way. Openness to experience pertains to the dimension that measures the individual's preference to display imagination, curiosity, originality, and open-mindedness. Conscientiousness can be found in discipline, responsibility, organization, reliability, and orderliness. Neuroticism refers to emotional instability; it is a tendency to experience mood swings and negative emotions. ${ }^{38}$

Various studies examined the Big Five model within the environment of social networks and found that extraversion is the most dominant characteristic that influences individuals' participation in social networks. ${ }^{39}$ However, other characteristics that were 
found to be relevant to individuals' social network use were neuroticism, openness to experience, agreeableness, and conscientiousness, although they were less dominant in their effect. ${ }^{40}$ The current study focuses on two personality characteristics derived from the Big Five (extraversion and openness to experience) as variables that may influence information professionals' and LIS students' Facebook use.

\section{Hypotheses}

Assuming that perceived ease of use, perceived enjoyment, personal innovativeness, and personal characteristics may predict information professionals' and LIS students' Facebook use, the underlying assumptions of this study are:

(H1). LIS students' level of Facebook perceived ease of use is higher than information professionals' level of Facebook perceived ease of use.

(H2). LIS students' level of Facebook perceived enjoyment is higher than information professionals' level of Facebook perceived enjoyment.

(H3). LIS students' level of personal innovativeness is higher than information professionals' level of personal innovativeness.

(H4). LIS students' Facebook use is greater than that of information professionals.

(H5). The more respondents perceive Facebook as easy to use, the greater their Facebook use.

(H6). The more perceived enjoyment respondents have, the greater their Facebook use. (H7). The higher respondents' personal innovativeness is, the greater their Facebook use.

(H8). The more extroverted respondents are, the greater their Facebook use

(H9). The more open to experience respondents are, the greater their Facebook use.

(H10). The younger respondents are, the higher their PEOU, perceived enjoyment, personal innovativeness, and the greater their Facebook use.

Some of the hypotheses are presented in figure 1.

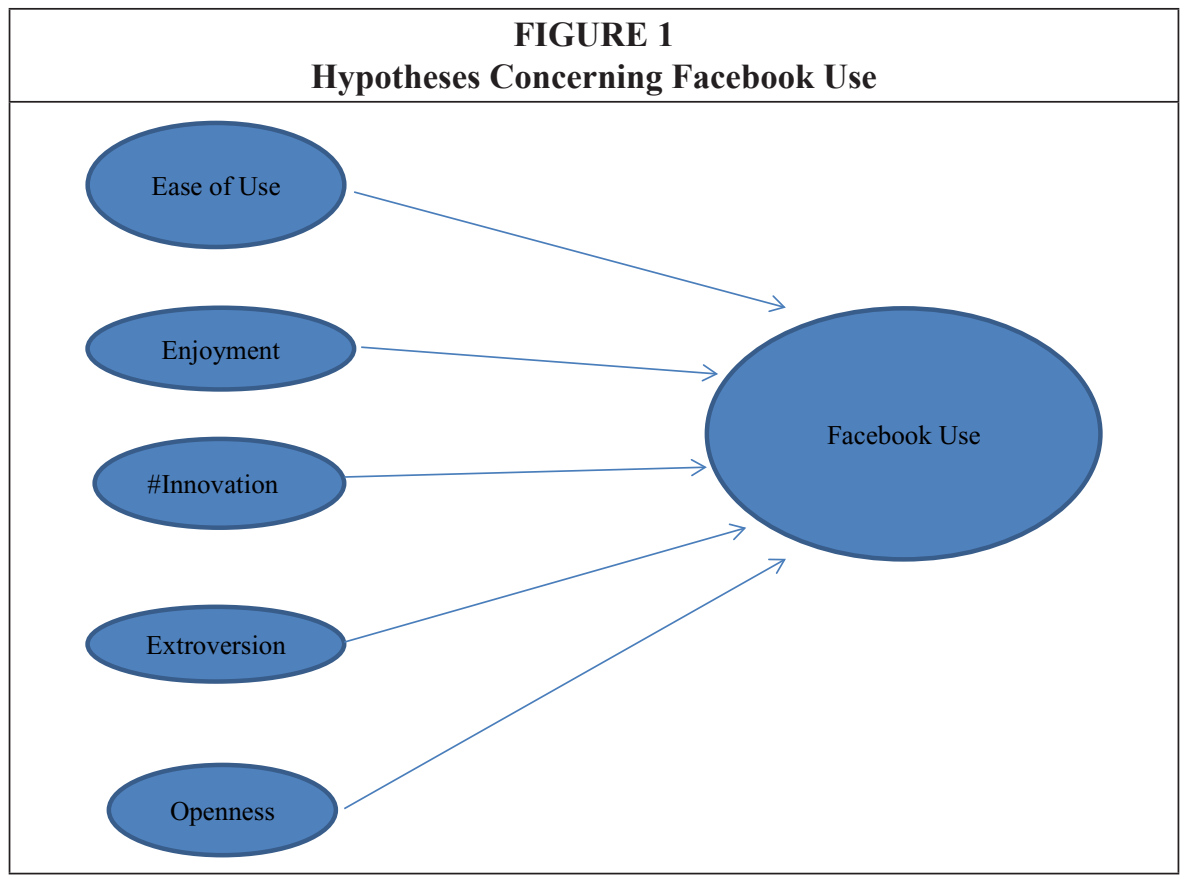




\section{Methodology}

\section{Participants and Data Collection}

The research was conducted in Israel during the first and second semesters of the 2013 academic year and encompassed two groups of participants: information professionals (who are academic librarians as well as information scientists in different organizations) and LIS students. The information professionals' average age was 46.68, while that of the LIS students was 35.94. To examine differences among the two groups concerning age, a t-test was conducted. A significant difference was found between the two groups, $=7.89, p<.001$.

The researchers sent a message and a questionnaire to an Israeli library and information science discussion group, an Israeli information specialist group, and an academic librarians' discussion group explaining the study's purpose and asking their members to complete the questionnaire. These three discussion groups (that play an important role in the Israeli LIS community) comprise about 1,000 members; 131 responses were received, giving a reply percentage of 13.1 percent. As for LIS students, there are approximately 800 enrolled nationwide. Researchers received permission to enter different courses in a prominent LIS department and delivered 160 questionnaires to the students. They explained the study's purpose to them, and $136(17 \%)$ responded. This research, therefore, had a total of 271 respondents.

\section{Measures}

Researchers used four questionnaires to gather the following data: personal details, Facebook use, attitudes toward Facebook, and personality characteristics derived from the Big Five.

The personal details questionnaire had two statements.

The Facebook use questionnaire consisted of four questions. Respondents' scores on three of the questions were aggregated into one measure according to the mean of the item scores. Higher scores indicated higher Facebook use. The value of Cronbach's Alpha was 80 .

The Facebook attitude questionnaire, based on Liu, Li, and Carlsson, was modified for this study and consisted of 11 statements rated on a 7-point Likert scale (1=strongest disagreement; $7=$ strongest agreement $).{ }^{41}$ The questionnaire had three factors. The first related to Facebook ease of use (items 1, 6, 8, 10); the second, to information professionals' personal innovativeness (items 2, 5, 9); and the third, to Facebook enjoyment (items 3, 4, 7, 11). The values of Cronbach's Alpha were .94, .90, and .94 respectively.

The personality characteristics, derived from the Big Five questionnaire, consisted of 18 statements rated on a 5-point Likert scale $(1=$ strongest disagreement; $5=$ strongest agreement). ${ }^{42}$ The questionnaire had two factors: extraversion (items 1, 3, 5, 7, 9, 11 ,

\begin{tabular}{|c|c|c|c|c|}
\hline \multicolumn{5}{|c|}{$\begin{array}{c}\text { TABLE } 1 \\
\text { Research Questionnaires }\end{array}$} \\
\hline & $\begin{array}{l}\text { Personal } \\
\text { Details }\end{array}$ & $\begin{array}{c}\text { Facebook } \\
\text { Use }\end{array}$ & $\begin{array}{c}\text { Facebook } \\
\text { Attitude }\end{array}$ & $\begin{array}{c}\text { Personality } \\
\text { Characteristics }\end{array}$ \\
\hline Number of Statements & 2 & 4 & 11 & 18 \\
\hline Number of Factors & & & $\begin{array}{l}3: \\
\text { items 1, 6, 8, } 10 \\
\text { items 2, 5,9 } \\
\text { items 3, 4, 7, } 11\end{array}$ & $\begin{array}{l}\text { 2: } \\
\text { items } 1,3,5,7,9 \text {, } \\
11,13,15 \\
\text { items } 2,4,6,8,10 \text {, } \\
12,14,16,17,18\end{array}$ \\
\hline Cronbach's Alpha & & .80 & $.94, .90, .94$ & $.82, .72$ \\
\hline
\end{tabular}


$13,15)$ and openness to experience (items $2,4,6,8,10,12,14,16,17,18$ ). The values of Cronbach's Alpha were .82, and .72, respectively.

The description of the questionnaires is presented below in table 1 .

\section{Results}

To examine whether there are differences between the two groups concerning variables related to the TAM (that is, PEOU, perceived enjoyment), and personal innovativeness, a series of one-way MANOVA was performed. The MANOVA revealed a significant difference between the two groups concerning the TAM variables, F $(3.267)=4.31, p$ $<.01, \eta^{2}=.05$. Means, standard deviations, and the univariate ANOVA analysis are presented in table 2 .

\begin{tabular}{|l|c|c|c|c|c|c|}
\hline \multicolumn{7}{|c|}{$\begin{array}{c}\text { TABLE 2 } \\
\text { Means and Standard Deviations of Respondents' Perceptions } \\
\text { towards Facebook }\end{array}$} \\
\hline \multirow{2}{*}{ Measures } & Information Professionals & Students \\
\cline { 2 - 7 } & $M$ & $S D$ & $M$ & $S D$ & $F(1.269)$ & $E t a^{2}$ \\
\hline PEOU & 5.27 & 1.55 & 5.70 & 1.31 & $6.18^{*}$ & .02 \\
\hline Enjoyment & 4.14 & 1.82 & 4.65 & 1.63 & $5.29 *$ & .02 \\
\hline Innovative & 4.82 & 1.56 & 4.76 & 1.53 & .10 & .00 \\
\hline$* p<.05$ & & & & \\
\hline
\end{tabular}

Table 2 shows that the ANOVA performed on each measure separately revealed significant differences between the two groups concerning the two measures: PEOU and enjoyment. It seems that students perceive Facebook as easier to use and more enjoyable than information professionals do.

To examine whether there are differences between the two groups concerning Facebook use, a one-way MANOVA was performed. The ANOVA revealed a significant difference between the two groups, $\mathrm{F}(1,269)=8.16, p<.01, \eta^{2}=.03$. It seems that students' use of Facebook is higher, $\mathrm{M}=1.83, \mathrm{SD}=.99$, than that of information professionals, $\mathrm{M}=1.49, \mathrm{SD}=.95$. To examine whether there are differences between the two groups concerning personality characteristics (extraversion and openness to experience), a MANOVA was performed that did not reveal a significant difference

\section{TABLE 3}

Pearson Correlations between Extraversion, Openness to Experience, the Tam Variables, Personal Innovativeness, and Facebook Use $(\mathbf{N}=\mathbf{2 7 1})$

\begin{tabular}{|l|c|c|c|c|c|c|}
\hline \multicolumn{1}{|c|}{ Measures } & Extraversion & Openness & PEOU & Enjoyment & Innovative & $\begin{array}{c}\text { Facebook } \\
\text { Use }\end{array}$ \\
\hline Extraversion & & & & & & \\
\hline Openness & $.43^{* * *}$ & & & & & \\
\hline PEOU & $.22 * * *$ & $.22 * * *$ & & & & \\
\hline Enjoyment & $.24 * *$ & $.23 * * *$ & $.64 * * *$ & & & \\
\hline Innovative & $.27 * * *$ & $.35^{* * *}$ & $.55^{* * *}$ & $.48^{* * *}$ & & \\
\hline Facebook Use & $.23 * * *$ & $.20^{* *}$ & $.53^{* * *}$ & $.69^{* * *}$ & $.42^{* * *}$ & \\
\hline$* * p<.01, * * * \mathrm{p}<.001$ &
\end{tabular}




\begin{tabular}{|l|c|c|c|c|}
\hline \multicolumn{5}{|c|}{ TABLE 4 } \\
Pearson Correlations Between Age, PEOU, Perceived Enjoyment, Personal \\
Innovativeness, and Facebook Use (N = 271) \\
\hline Measures & PEOU & Enjoyment & Innovative & Facebook Use \\
\hline Age & $-.28 * * *$ & $-.27 * * *$ & -.13 & $-.40 * * *$ \\
\hline$* * * \mathrm{p}<.001$ & \multicolumn{5}{|l}{} \\
\hline
\end{tabular}

between the two groups concerning personality characteristics, $\mathrm{F}(2,268)=2.13, p>.05$. Pearson correlations were performed to examine the relationship between extraversion, openness to experience, the TAM variables, personal innovativeness, and Facebook use; the correlations are shown in table 3.

Table 3 shows that significant positive correlations were found between extraversion, openness to experience, the TAM variables, personal innovativeness, and Facebook use. Hence, the more extraverted and open to experience respondents are, the more they use Facebook. Furthermore, significant high correlations were found between the TAM variables (PEOU, perceived enjoyment), personal innovativeness, and Facebook use. Thus, the more respondents perceive Facebook as easy to use, enjoyable, and are more personally innovative, the more they use it. Pearson correlations were also performed to examine the relationship between age and PEOU, perceived enjoyment, personal innovativeness, and Facebook use; these findings are presented in table 4.

Table 4 shows significant negative correlations between age and PEOU, perceived enjoyment, personal innovativeness, and Facebook use. Hence, the older respondents are, the lower their perceptions about Facebook and the lower their Facebook use.

Researchers also conducted a hierarchical regression using Facebook use as a dependent variable. The predictors were entered as four steps: (1) respondents' age; (2)

TABLE 5

Hierarchical Regression Coefficients of Respondents' Facebook Use $(n=271)$

\begin{tabular}{|c|c|c|c|c|c|}
\hline \multicolumn{2}{|c|}{ Predictors } & \multirow{2}{*}{$\begin{array}{c}\mathrm{B} \\
-.03 \\
\end{array}$} & \multirow{2}{*}{$\begin{array}{c}\beta \\
-.40 * * * \\
\end{array}$} & \multirow{2}{*}{$\begin{array}{c}\mathrm{R}^{2} \\
.16^{* * * *} \\
\end{array}$} & \multirow{2}{*}{$\begin{array}{c}\Delta \mathrm{R}^{2} \\
.16^{* * * *}\end{array}$} \\
\hline 1. & Age & & & & \\
\hline \multirow[t]{3}{*}{2.} & Age & -.03 & $-.42 * * *$ & $.26 * * *$ & $.10^{* * *}$ \\
\hline & Extraversion & .31 & $.22 * *$ & & \\
\hline & Openness & .24 & .10 & & \\
\hline \multirow[t]{5}{*}{3.} & Age & -.02 & $-.30 * * *$ & $.40 * * *$ & $.14 * * *$ \\
\hline & Extraversion & .18 & .13 & & \\
\hline & Openness & .07 & .04 & & \\
\hline & PEOU & .21 & $.31 * * *$ & & \\
\hline & Innovative & .10 & .15 & & \\
\hline \multirow[t]{6}{*}{4.} & Age & -.01 & -.24 & $.57 * * *$ & $.17^{* * *}$ \\
\hline & Extraversion & .09 & .12 & & \\
\hline & Openness & .04 & .02 & & \\
\hline & PEOU & .01 & .02 & & \\
\hline & Innovative & .05 & .08 & & \\
\hline & Enjoyment & .31 & $.55 * * *$ & & \\
\hline \multicolumn{6}{|c|}{$* * \mathrm{p}<.01, * * * \mathrm{p}<.001$} \\
\hline
\end{tabular}


personality characteristics (extraversion and openness to experience); (3) PEOU and personal innovativeness; (4) perceived enjoyment. The regression explained 57 percent of Facebook use. Table 5 presents the standardized and unstandardized coefficients of the hierarchical regression of respondents' Facebook use.

The first step introduced the age variable that contributed significantly by adding 16 percent to the explained variance of Facebook use. The beta coefficient of the age variable is negative; hence, the older respondents are, the less they use Facebook. The second step introduced the two personality characteristics (extraversion and openness to experience) that contributed 10 percent to the explained variance of Facebook use. Of these two variables, only the extraversion variable contributed significantly and its beta coefficient was positive. In other words, the more extraverted respondents are, the more they use Facebook.

As the third step, researchers added respondents' perceptions about their PEOU and personal innovativeness; this also contributed significantly, by adding 14 percent to the explained variance of Facebook use. The beta coefficients of the two variables were positive, and we may therefore conclude that the more respondents perceived themselves as personally innovative, and Facebook as easy to use, the more they use Facebook. The inclusion of this step caused a decrease in the $\beta$ size of extraversion and of the age variables that may suggest a possibility of mediation. Sobel test indicated that PEOU mediates between extraversion and Facebook use $(z=3.49, p<.001)$, as well as between age and Facebook use $(z=4.42, p<.001)$. Therefore, the more extraverted and younger respondents are, the higher their PEOU; as a result, the higher is their Facebook use.

The fourth step added respondents' perceptions about Facebook enjoyment; this also contributed significantly, by adding 17 percent to the explained variance of Facebook use. The beta coefficient of this variable was positive, signifying that the more respondents perceived Facebook as enjoyable, the greater their use of the site. Note that in this step there was a decrease in the $\beta$ size of PEOU. Sobel test indicated that enjoyment mediates between PEOU and Facebook use $(z=8.34, p<.001)$. Thus, the more respondents perceive Facebook as easy to use, the higher their perception about Facebook enjoyment and, as a result, the more they use Facebook.

\section{Discussion}

Researchers divided the study hypotheses into four categories. The first $(\mathrm{H} 1-\mathrm{H} 4)$ refers to the differences between information professionals' and LIS students' Facebook use. The second (H5-H7) relates to the influence of TAM on Facebook use; the third (H8-H9), to the effect of personality characteristics on Facebook use. The final category (H10) relates to the demographic characteristic. Addressing the first category findings reveal that three of the four hypotheses $(\mathrm{H} 1, \mathrm{H} 2, \mathrm{H} 4)$ were accepted. It seems that LIS students' perceptions about Facebook PEOU and perceived enjoyment are higher than information professionals' and that they use Facebook more than information professionals do. These findings are not surprising and may be associated with H10, which focused on respondents' age. Recall that, in the current study, LIS students are younger than information professionals. Hence, it was not unexpected to find that LIS students perceive Facebook as easier to use and more enjoyable and that they use Facebook more often than the information professionals who are older.

The finding that younger respondents use Facebook more than older ones echoes results presented by Rainie, which suggest that 86 percent of Facebook users are young (18-29 years old). ${ }^{43}$ Therefore, we may understand as well why those younger respondents perceive Facebook as easy to use and enjoyable. Directors of information organizations should be aware of these findings and try to expose their older employees 
to social networks such as Facebook, while emphasizing the personal and professional benefits to them. They should explain to their staffs that younger people are heavy users of social networks. ${ }^{44}$ Therefore, it would be advantageous if they try to reach their younger patrons via Facebook and to establish rapport with students through it. ${ }^{45}$ They can emphasize that libraries can use Facebook for the following activities: marketing their services, sending various announcements to their users, answering reference questions, using the "wall" for answering queries, having different links on Facebook pages such as RSS to librarians' blogs and search options, uploading photos, establishing forums for users, and using Facebook for information literacy instruction. ${ }^{46}$

Findings addressing $\mathrm{H} 3$ presents that LIS students are not more personally innovative than information professionals. This can be explained as follows: Agarwal and Prasad noted that personal innovativeness is a stable personality characteristic across situational considerations. ${ }^{47}$ We may then conclude that it does not matter if the respondent is a student or an information professional, or if s/he is young or old, as the personality characteristic is the most dominant feature and not the respondent's role.

Findings concerning the second category (H5, H6, and H7) reveal that these three hypotheses were accepted. It seems that, the more respondents perceived Facebook as easy to use and enjoyable, and the more they are personally innovative, the more they use Facebook. These findings can be associated with those of van der Heijden, who found that, in hedonic environments (such as Facebook), perceived enjoyment and perceived ease of use are the major variables that affect respondents' intention to use technology; in our study, it affected their actual Facebook use. ${ }^{48}$ Yet it should be remembered that Facebook, in our case, was not considered a hedonic environment but a work one. Therefore, information organizations directors and LIS educators should point out the advantages of this platform, persuading their employees and students that it is not only a platform that one can enjoy or have fun with; it can also serve as a simple and enjoyable work platform. Understanding that library employees may feel nervous or threatened by the new situation, they may use the 23 Things Learning 2.0 program or Seiner's guide for the creation of library-based social media; both aim to develop Web 2.0 capabilities in library staff. ${ }^{49}$

Concerning H7, it was not unanticipated that the more personally innovative respondents are, the more they use Facebook. This finding addresses Agarwal and Prasad's suggestion that innovative people are willing to try out newer information technology and are more likely to take advantage of technologies such as Facebook. ${ }^{50}$

The third category pertained to personality characteristics' influence on Facebook use (H8, H9). Both hypotheses were accepted. Findings show that, the more extraverted and open to experience respondents are, the more they use Facebook. These results are consistent with previous studies suggesting that extraversion is the most dominant characteristic influencing individuals' participation in social networks. ${ }^{51}$ Openness to experience is also relevant to an individual's social network use. ${ }^{52}$ These findings may help directors of information organizations when choosing staff who work with social networks. They should be aware of personality differences and understand that not each information professional can work and do his or her best on social platforms. Accordingly, they should decide who on their staff is extraverted or open to experience, to choose the most suitable employees who will make the best use of the Facebook platform.

The last category, addressing the demographic variable of age (H10), was also accepted and suggests that age is a very important factor when considering Facebook use. Findings reveal that the younger respondents are, the higher their PEOU, perceived enjoyment, and personal innovativeness and the greater their Facebook use. In other words, the current findings echo previous ones that proposed that 18-24-year-olds 
made up the largest group of users..$^{53}$ Hence, the younger respondents are, the more they use Facebook and, as a result, the more they enjoy it and perceive its ease of use. Information organizations directors, as well as LIS educators, should bear this finding in mind and train older employees or students to use Facebook as an avenue to reach their patrons. They should expose them to a Facebook environment when they are still students, thus reducing their level of threat and uncertainty, and show them the advantages that can be derived from its use (for example, participating in professional groups, interacting with the younger generation, and enhancing the image of their workplace).

\section{Limitations and Conclusions}

This study has several limitations. The first is that Israel's population is small in comparison with North America's; because of the response rate, we suggest that this study will be perceived as an exploratory one. Second, the research focused only on the Israeli LIS community. Therefore, researchers recommend that, if an international LIS perspective toward Facebook use is to be achieved, the study should be conducted in other countries as well. Moreover, to better understand the phenomenon of Facebook, and to explore which factors are associated with its acceptance or nonacceptance, we suggest that a future study may also use qualitative methods to enrich the findings by adding other dimensions to the inquiry process. In addition, further research may address practical characteristics of Facebook professional use as well. In other words, it can analyze actual use of Facebook in information organizations, delving into the advantages or disadvantages it presents to workplaces.

Based on the premises of the TAM, and some characteristics of the "Big Five" model, the present research explored to what extent the TAM, personal innovativeness, extraversion, and openness to experience explain information professionals' and LIS students' Facebook use. By addressing these questions, this article makes a number of theoretical and practical contributions. It expands the scope of research about the TAM by examining it within the context of Facebook, emphasizing the importance of perceived enjoyment as a variable that predicts Facebook use. Furthermore, it confirms that the TAM, as well as other personal characteristics, significantly predict the likelihood of Facebook use and highlight the importance of individual characteristics when considering technology acceptance. In addition, the current study points out that directors of information organizations and LIS departments should be familiar with both the TAM and the issue of individual differences, as well as with the possible uses of Facebook in information organizations. If those directors come to the conclusion that Facebook is a good professional instrument that might improve and upgrade their organization's functioning, the mentioned factors (TAM variables and personality characteristics) may help them choose the most appropriate employees and students, as well as understand threatened and/or unmotivated workers or students. Moreover, the study suggests that there are differences between the two groups concerning Facebook PEOU, perceived enjoyment, and Facebook use. Hence, we believe that, when directors of information organizations are convinced with Facebook's advantages, the more they expose their workers to it and the higher information professionals' perceptions toward Facebook will be. 


\section{Appendix A. Information Professionals' and Students' Questionnaire}

\section{Personal Details}

1. Male / Female

2. Age:

\section{Facebook Usage Questionnaire}

1. How many hours do you spend every day in Facebook?
a. Less than an hour
b. Between 1 hour and 2 hours
c. Between 2 and 3 hours
d. More than 3 hours

2. How many friends do you have on Facebook?
a. Less than 10
b. Between 10 to 50
c. Between 50 to 100
d. More than 100

3. How many times a day so you update your status?
a. Less than once a day
b. At least once a day
c. Till five times a day
d. More than five times a day
e. How often do you use Facebook
f. Don't use
g. Quite often

\section{Appendix B. Information Professionals' and Students' Perceptions about Facebook use}

Below are statements concerning your attitudes towards the assimilation of Facebook in your organization. Please mark with $\mathrm{X}$ the column which describes your accordance with the following statements ( $1=$ not at all; $7=$ at a very high level)

\begin{tabular}{|l|l|l|l|l|l|l|l|}
\hline Statement & $\begin{array}{l}\text { 1. Not } \\
\text { at all }\end{array}$ & $\begin{array}{l}\text { 2. Very } \\
\text { Limited }\end{array}$ & $\begin{array}{l}\text { 3. } \\
\text { Slightly }\end{array}$ & $\begin{array}{l}\text { 4. Almost } \\
\text { Average } \\
\text { Level }\end{array}$ & $\begin{array}{l}\text { 5. Average } \\
\text { Level }\end{array}$ & $\begin{array}{l}\text { 6. More } \\
\text { than } \\
\text { Average }\end{array}$ & $\begin{array}{l}\text { 7. } \\
\text { High } \\
\text { Level }\end{array}$ \\
\hline $\begin{array}{l}\text { It is easy to use } \\
\text { Facebook }\end{array}$ & & & & & & & \\
\hline $\begin{array}{l}\text { If I hear about } \\
\text { a new informa- } \\
\text { tion technology, } \\
\text { I would look for } \\
\text { ways to experi- } \\
\text { ence with it }\end{array}$ & & & & & & & \\
\hline $\begin{array}{l}\text { Using Facebook is } \\
\text { interesting }\end{array}$ & & & & & & & \\
\hline
\end{tabular}




\begin{tabular}{|l|l|l|l|l|l|l|l|}
\hline Statement & $\begin{array}{l}\text { 1. Not } \\
\text { at all }\end{array}$ & $\begin{array}{l}\text { 2. Very } \\
\text { Limited }\end{array}$ & $\begin{array}{l}\text { 3. } \\
\text { Slightly }\end{array}$ & $\begin{array}{l}\text { 4. Almost } \\
\text { Average } \\
\text { Level }\end{array}$ & $\begin{array}{l}\text { 5. Average } \\
\text { Level }\end{array}$ & $\begin{array}{l}\text { 6. More } \\
\text { than } \\
\text { Average }\end{array}$ & $\begin{array}{l}\text { 7. } \\
\text { High } \\
\text { Level }\end{array}$ \\
\hline $\begin{array}{l}\text { Using Facebook is } \\
\text { exciting }\end{array}$ & & & & & & & \\
\hline $\begin{array}{l}\text { I like to experi- } \\
\text { ence with new } \\
\text { information tech- } \\
\text { nologies }\end{array}$ & & & & & & & \\
\hline $\begin{array}{l}\text { Using Facebook is } \\
\text { free of efforts }\end{array}$ & & & & & & & \\
\hline $\begin{array}{l}\text { Using Facebook is } \\
\text { enjoyable }\end{array}$ & & & & & & & \\
\hline $\begin{array}{l}\text { It is easy to } \\
\text { become skillful at } \\
\text { Facebook }\end{array}$ & & & & & & & \\
\hline $\begin{array}{l}\text { Among my } \\
\text { friends, I'm the } \\
\text { first one to try out } \\
\text { new information } \\
\text { technologies }\end{array}$ & & & & & & & \\
\hline $\begin{array}{l}\text { Using Facebook } \\
\text { is clear }\end{array}$ & & & & & & & \\
\hline $\begin{array}{l}\text { Using Facebook is } \\
\text { pleasant }\end{array}$ & & & & & & & \\
\hline
\end{tabular}

\section{Appendix C. Personality Questionnaire}

Here are a number of characteristics that may or may not apply to you. For example, do you agree that you are someone who likes to spend time with others? Please write a number next to each statement to indicate the extent to which you agree or disagree with that statement $(1=$ not at all; $5=$ at a very high level).

\begin{tabular}{|l|l|l|l|l|l|}
\hline $\begin{array}{l}\text { I see Myself as Someone } \\
\text { Who... }\end{array}$ & $\begin{array}{l}\text { 1. Disagree } \\
\text { strongly }\end{array}$ & $\begin{array}{l}\text { 2. Disagree } \\
\text { a little }\end{array}$ & $\begin{array}{l}\text { 3. Neither } \\
\text { agree nor } \\
\text { disagree }\end{array}$ & $\begin{array}{l}\text { 4. Agree } \\
\text { a little }\end{array}$ & $\begin{array}{l}\text { 5. Agree } \\
\text { strongly }\end{array}$ \\
\hline Is talkative & & & & & \\
\hline $\begin{array}{l}\text { Is original, comes up with } \\
\text { new ideas }\end{array}$ & & & & & \\
\hline Is reserved & & & & & \\
\hline $\begin{array}{l}\text { Is curious about many dif- } \\
\text { ferent things }\end{array}$ & & & & & \\
\hline Is full of energy & & & & & \\
\hline Is ingenious, a deep thinker & & & & & \\
\hline $\begin{array}{l}\text { Generates a lot of enthu- } \\
\text { siasm }\end{array}$ & & & & & \\
\hline
\end{tabular}


Factors Affecting Adoption of Facebook 891

\begin{tabular}{|c|c|c|c|c|c|}
\hline $\begin{array}{l}\text { I see Myself as Someone } \\
\text { Who... }\end{array}$ & $\begin{array}{l}\text { 1. Disagree } \\
\text { strongly }\end{array}$ & $\begin{array}{l}\text { 2. Disagree } \\
\text { a little }\end{array}$ & $\begin{array}{l}\text { 3. Neither } \\
\text { agree nor } \\
\text { disagree }\end{array}$ & $\begin{array}{l}\text { 4. Agree } \\
\text { a little }\end{array}$ & $\begin{array}{l}\text { 5. Agree } \\
\text { strongly }\end{array}$ \\
\hline \multicolumn{6}{|l|}{ Has an active imagination } \\
\hline \multicolumn{6}{|l|}{ Tends to be quiet } \\
\hline \multicolumn{6}{|l|}{ Is inventive } \\
\hline \multicolumn{6}{|l|}{$\begin{array}{l}\text { Has an assertive personal- } \\
\text { ity }\end{array}$} \\
\hline \multicolumn{6}{|l|}{$\begin{array}{l}\text { Values artistic, aesthetic } \\
\text { experience }\end{array}$} \\
\hline \multicolumn{6}{|l|}{ Is sometimes shy, inhibited } \\
\hline \multicolumn{6}{|l|}{ Prefers work that is routine } \\
\hline \multicolumn{6}{|l|}{ Is outgoing, sociable } \\
\hline \multicolumn{6}{|l|}{$\begin{array}{l}\text { Likes to reflect, play with } \\
\text { ideas }\end{array}$} \\
\hline \multicolumn{6}{|l|}{ Has few artistic interests } \\
\hline $\begin{array}{l}\text { Is sophisticated in art, } \\
\text { music, or literature }\end{array}$ & & & & & \\
\hline
\end{tabular}

\section{Notes}

1. Dana Boyd and Nicole Ellison, "Social Network Sites: Definition, History, and Scholarship," Journal of Computer-Mediated Communication 13, no. 1 (2007): 210-30.

2. Ibid., 211.

3. Norazah Suki, T. Ramayah, and Ker Kee Ly, "Empirical Investigation on Factors Influencing the Behavioral Intention to Use Facebook," Universal Access in the Information Society 11, no. 2 (2012): 223-31.

4. Mark Urista, Qingwen Dong, and Kenneth Day, "Explaining Why Young Adults Use Myspace and Facebook through Uses and Gratifications Theory," Human Communication 12, no. 2 (2009): 215-29.

5. Lee Rainie, "The State of Facebook: Slide Presentation during Facebook Fatigue: Fact or Fiction," program given in March 2013 by the Internet \& American Life Project, Pew Research Center, Washington, D.C., available online at www.pewinternet.org/Presentations/2013/Mar/The-Stateof-Facebook.aspx [accessed 6 June 2013 ].

6. Meredith Farkas, Social Software in Libraries (Medford, N.J.: Information Today, Inc.., 2007), 122; Terra B. Jacobson, "Facebook as a Library Tool: Perceived vs. Actual Use, " College \& Research Libraries 72, no. 1 (2011): 79-90.

7. Laurie Charnigo and Paula Barnett-Ellis, "Checking Out Facebook.com: The Impact of a Digital Trend on Academic Libraries," Information Technology and Libraries 26, no. 1 (2007): 30.

8. Daniel Mack, Anne Behler, Beth Roberts, and Emily Rimland, "Reaching Students with Facebook: Data and Best Practices," Electronic Journal of Academic and Special Librarianship 8, no. 2 (2007), available online at http://southernlibrarianship.icaap.org/ indexv8.html [accessed 28 August 2013].

9. Randy Reichardt, "How May I Help Thee? Let Me Count The 2.0 Ways..." Internet Reference Services Quarterly, 13, no. 2/3 (2008): 271-80; Jo Alcock, "Using Facebook Pages to Reach Users: The Experiences of University of Wolverhampton, "ALISS Quarterly 4, no. 2 (2009): 2-6.

10. Nancy Kim Phillips, "Academic Library Use of Facebook: Building Relationships with Students," Journal of Academic Librarianship 37, no. 6 (2011): 512-22; Dean Hendrix, Deborah Chiarella, and Michelle Zafron, "Use of Facebook in Academic Health Sciences Libraries," Journal of the Medical Library Association 97, no. 1 (2009): 44-47.

11. Melanie Chu and Yvonne Nalani Meulemans, "The Problems and Potential of MySpace 
and Facebook Usage in Academic Libraries," Internet Reference Services Quarterly 13, no. 1 (2007): 80-84.

12. Rolando Garcia, Norton Hanna, and Michele Tennant, "The Presence of Academic Health Sciences Libraries on Facebook: The Relationship between Content and Library Popularity," Medical Service Quarterly 31 no. 2 (2012): 171-87.

13. Terra B. Jacobson, "Facebook as a Library Tool: Perceived vs. Actual Use," College \& Research Libraries 72, no. 1 (2011): 79-90.

14. Edit Falk and Luba Gorenstein, "The Academic Library: Researchers Perspectives. Researchers and Ph. D. Students' Library Satisfaction Assessment," Meidaat 6 (2010) : 31-45.

15. Hanie Haetz, Shifra Baruchson-Arbib, Nira Shalom, and Jenny Bronstein, "Managing Public Libraries in the Age of Change," Meidaat 6 (2010): 4-30.

16. Noa Aharony, "Facebook Use by Library and Information Science Students," Aslib Proceedings 65, no.1 (2013): 19-39; Noa Aharony, "Facebook Use in Libraries: An Exploratory Analysis," Aslib Proceedings 64, no. 4 (2012): 358-72; Hanna Carlsson, "Working with Facebook in Public Libraries: A Backstage Glimpse into the Library 2.0 Rhetoric," Libri 62, no. 3 (2012): 199-210; Ruth Connell, "Academic Libraries, Facebook and MySpace, and Student Outreach: A Survey of Student Opinion," portal: Libraries and the Academy 9, no. 1 (2009): 25-36; Terra Jacobson, "Facebook as a Library Tool: Perceived vs. Actual Use," College and Research Libraries 72, no. 1(2011): 79-90; Nancy Phillips, "Academic Library Use of Facebook: Building Relationships with Students," Journal of Academic Librarianship 37, no. 6 (2011): 512-22; Mark-Shane Scale, "Facebook as a Social Search Engine and the Implications for Libraries in the Twenty-First Century," Library Hi Tech 26, no. 4 (2008): 540-56.

17. Fred Davis, "Perceived Usefulness, Perceived Ease of Use, and User Acceptance of Information Technology," MIS Quarterly 13, no. 3 (1989): 319-39; Viswanath Venkatesh and Michael Morris, "Why Don't Men Ever Stop to Ask for Directions? Gender, Social Influence, and Their Role in Technology Acceptance and Usage Behavior," MIS Quarterly 24, no. 1 (2000): 115--39.

18. Lewis Goldberg, "An Alternative Description of Personality: The Big-Five Factor Structure," Journal of Personality and Social Psychology 59, no. 6 (1990): 1216-29.

19. Martin Fishbein and Icek Ajzen, Belief, Attitude, Intention and Behavior: An Introduction to Theory and Research (Reading, Mass.: Addison-Wesley, 1975).

20. Davis, "Perceived Usefulness, Perceived Ease of Use, and User Acceptance of Information Technology."

21. Ritu Agarwal and Jayesh Prasad, "A Conceptual and Operational Definition of Personal Innovativeness in the Domain of Information Technology," Information Systems Research 9, no. 2 (1998): 204-15; Fred Davis, Richard Bagozzi, and Paul Warshaw, “User Acceptance of Computer Technology: A Comparison of Two Theoretical Models," Management Science 35, no. 8 (1989): 982-1003; Cynthia Jackson, Simeon Chow, and Robert Leitch, "Toward an Understanding of the Behavioral Intention to Use an Information System," Decision Sciences 28, no. 2 (1997): 357-89; Viswanath Venkatesh, "Creation of Favorable Uses Perceptions: Exploring the Role of Intrinsic Motivation," MIS Quarterly 23, no. 2 (1999): 239-60.

22. Fred Davis, Richard Bagozzi, and Paul Warshaw, "Extrinsic and Intrinsic Motivation to Use Computers in the Workplace," Journal of Applied Social Psychology 22 (1992): 1111-32.

23. Hans van der Heijden, "User Acceptance of Hedonic Information Systems," MIS Quarterly 28, no. 4 (2004): 695-704; Merriam-Webster Dictionary, Hedonism (2013), available online at www. merriam-webster.com/dictionary/hedonism?show=0\&t=1361951852 [accessed 10 June 2013 ].

24. van der Heijden, "User Acceptance of Hedonic Information Systems."

25. Ibid.

26. Gordon Bruner and Anand Kumar, "Explaining Consumer Acceptance of Hand-Held Internet Devices," Journal of Business Research 58, no. 5 (2005): 553-58; J-Won Moon, and Young-Gul Kim, "Extending the TAM for a World-Wide-Web Context," Information \& Management 38, no. 4 (2001): 217-30; Hans van der Heijden, "Factors Influencing the Usage of Websites: The Case of a Generic Portal in the Netherlands," Information Management 40, no. 6 (2003): 541-49; Robert Kraut, Vicki Lundmark, Michael Patterson, Sara Kiesler, Tridas Mukopadhyay, and William Scherlis, "Internet Paradox: A Social Technology that Reduces Social Involvement and Psychological WellBeing?" American Psychologist 53, no. 10 (1998): 17-31; Viswanath Venkatesh and Suzan Brown, "A Longitudinal Investigation of Personal Computers in Homes: Adoption Determinants and Emerging Challenges," MIS Quarterly 25, no. 1 (2001): 71-102; Young Kang and Heeseok Lee, "Understanding the Role of an IT Artifact in Online Service Continuance: An Extended Perspective of User Satisfaction," Computers in Human Behavior 26, no. 3 (2010): 353-64; Deb Sledgianowski and Songpol Kulviwat, "Using Social Network Sites: The Effects of Playfulness, Critical Mass and Trust in a Hedonic Context," Journal of Computer Information Systems 49, no. 4 (2009): 74-83.

27. van der Heijden, "User Acceptance of Hedonic Information Systems."

28. Viswanath Venkatesh and Fred Davis, "A Theoretical Extension of the Technology Accep- 
tance Model: Four Longitudinal Field Studies," Management Sciences 46, no. 2 (2000):186-204; Elena Karahanna and Moez Limayem, "E-mail and V-Mail Usage: Generalizing Across Technologies," Journal of Organizational Computing and Electronic Commerce 10, no. 1 (2000): 49-66; David Gefen and Detmar Straub, "Gender Difference in the Perception and Use of Email: An Extension to the Technology Acceptance Model," MIS Quarterly 21, no. 4 (1997): 389-400; Detmar Straub, "The Effect of Culture on IT Diffusion: E-Mail and FAX in Japan and the U.S.," Information Systems Research 5, no. 1 (1994): 23-47; Henri Barki and Jon Hartwick, "Measuring User Participation, User Involvement, and User Attitude," MIS Quarterly 18, no. 1 (1994): 59-82.

29. Davis, Bagozzi, and Warshaw, "User Acceptance of Computer Technology"; David Gefen, Elena Karahanna, and Detmar Straub, "Trust and TAM in Online Shopping: An Integrated Model," MIS Quarterly 27, no. 1 (2003): 51-90; 28. Min-Ho Ryu, Seongcheol Kim, and Euehun Lee, "Understanding the Factors Affecting Online Elderly Users' Participation in Video UCC Services," Computers in Human Behavior 25, no. 1 (2009): 619-32; Paul Hu, Patrick Chau, Olivia Sheng, and Kar Tam, "Examining the Technology Acceptance Model Using Physician Acceptance of Telemedicine Technology," Journal of Management Information Systems, 16, no. 2 (1999): 91-112.

30. Qingxiong Ma and Liping Liu, "The Technology Acceptance Model: A Meta-Analysis of Empirical Findings," Journal of Organizational and End User Computing 16, no. 1 (2004): 59-72; Shumaila Yousafzai, Gordon Foxall, and John Pallister, "Technology Acceptance: A Meta-Analysis of the TAM," Journal of Modelling in Management 2, no. 3 (2007): 251-80.

31. Everett Rogers, "Diffusion of Innovations," 3rd ed. (New York: Free Press, 1983); Everett Rogers, "Diffusion of Innovations," 4th ed. (New York: Free Press).

32. Everett Rogers, "Diffusion of Innovations," 7th ed. (New York: Free Press, 2003).

33. Agarwal and Prasad, "A Conceptual and Operational Definition of Personal Innovativeness in the Domain of Information Technology."

34. June Lu, James Yao, and Chun-Sheng Yu, "Personal Innovativeness, Social Influences and Adoption of Wireless Internet Services via Mobile Technology," Journal of Strategic InformationSystems, 14, no. 3 (2005): 245-68.

35. Nimet Uray and Alya Dedeoglu, "Identifying Fashion Clothing Innovators by Self-Report Method," Journal of Euromarketing 6, no. 3 (1997): 27-46; P.M. Venkatraman, “The Impact of Innovativeness and Innovation Type and Adoption," Journal of Retailing 67, no. 1 (1991): 51-67.

36. Costa, P., Jr., \& McCrae, R. (1992). NEO personality inventory-revised (NEO-PI-R) and NEO five-factor inventory (NEO-FFI) professional manual. Odessa, FL: Psychological Assessment Resources; Lewis Goldberg, "The Structure of Phenotypic Personality Traits," American Psychologist 48, no. 1 (1993): 26-34; Mary T. Russell and Darcie L. Karol, "Administrator's Manual 16PF," 5th ed. (Champaign, Ill.: Institute for Personality and Ability Testing, 1994).

37. Ernest C. Tupes and Raymond E. Christal, "Recurrent Personality Factors Based on Trait Ratings," Journal of Personality 60, no. 2 (1992): 225-51.

38. Yoram Bachrach, Michal Kosinski, Thore Graepel, Pushmeet Kohli, and David Stillwell, "Personality and Patterns of Facebook Usage," paper presented at WebSci, June 22-24, 2012, Evanston, Ill.; Gwendolyn Seidman, "Self-Presentation and Belonging on Facebook: How Personality Influences Social Media Use and Motivations," Personality and Individual Differences 54, no. 3 (2013): 402-07.

39. Samuel Gosling, Adam Augustine, Simine Vazire, Nicholas Holtzman, and Sam Gaddis, "Manifestations of Personality in Online Social Networks: Self-Reported Facebook-Related Behaviors and Observable Profile Information," Cyberpsychology, Behavior, and Social Networking 14, no. 9 (2011): 483-88; Stefan Wehrli, "Personality on Social Network Sites: An Application of the Five Factor Model," ETH Zurich Sociology Working Paper No. 7 (2008), available online at http:// repec.ethz.ch/ets/papers /wehrli_studivz_big5.pdf [accessed 15 May 2013]; Kathryn Wilson, Stephanie Fornasier, and Katherine White, "Psychological Predictors of Young Adults' Use of Social Networking Sites," Cyberpsychology, Behavior, and Social Networks 13, no. 2 (2010): 173-77; Jolene Zywica and James Danowski, "The Faces of Facebookers: Investigating Social Enhancement and Social Compensation Hypotheses," Journal of Computer-Mediated Communication 14, no. 1 (2008): 1-34.

40. Alexandra Ehrenberg, Suzanna Juckes, Katherine M. White, and Shari P. Walsh, "Personality and Self-Esteem as Predictors of Young People's Technology Use," CyberPsychology \& Behavior 11, no. 6 (2008): 739-41; Craig Ross, Emily Orr, Mia Sisic, Jaime Arseneault, Mary Simmering, and Robert Orr, "Personality and Motivations Associated with Facebook Use," Computers in Human Behavior 25, no. 2 2009: 578-86; Seidman, "Self-Presentation and Belonging on Facebook"; Wehrli, "Personality on Social Network Sites"; Maarten Selfhout, William Burk, Susan Branje, Jaap Denissen, Marcel van Aken, and Wim Meeus, "Emerging Late Adolescent Friendship Networks and Big Five Personality Traits: A Social Network Approach," Journal of Personality 78, no. 2 (2010): 509-38; Tracil Ryan and Sophia Xenos, "Who Uses Facebook? An Investigation into the Relationship between the Big Five, Shyness, Narcissism, Loneliness, and Facebook Usage," Computers in 
Human Behavior 27, no. 5 (2012): 1658-64.

41. Yong Liu, Hongxiu Li, and Christer Carlsson, "Factors Driving the Adoption of M-Learning: An Empirical Study," Computers \& Education 55, no. 3 (2010): 1211-19.

42. Oliver P. John, Eileen M. Donahue, and Robert L. Kentle, The Big Five Inventory: Versions $4 a$ and 54 (Berkeley, Calif.: University of California, Institute of Personality and Social Research, 1991).

43. Rainie, "The State of Facebook: Slide Presentation during Facebook Fatigue: Fact or Fiction."

44. Meredith Farkas, Social Software in Libraries (Medford, N.J.: Information Today, Inc., 2007); Jacobson, "Facebook as a Library Tool: Perceived vs. Actual Use."

45. Phillips, "Academic Library Use of Facebook."

46. Farkas, Social Software in Libraries; Jacobson, "Facebook as a Library Tool"; Hendrix, Chiarella, and Zafron, "Use of Facebook in Academic Health Sciences Libraries"; Mack, Behler, Roberts, and Rimland, "Reaching Students with Facebook: Data and Best Practices"; Chu and Meulemans, "The Problems and Potential of MySpace and Facebook Usage in Academic Libraries."

47. Agarwal and Prasad, "A Conceptual and Operational Definition of Personal Innovativeness in the Domain of Information Technology."

48. van der Heijden, "User Acceptance of Hedonic Information Systems."

49. Agarwal and Prasad, "A Conceptual and Operational Definition of Personal Innovativeness in the Domain of Information Technology"; Gosling, Augustine, Vazire, Holtzman, and Gaddis, "Manifestations of Personality in Online Social Networks"; Wehrli, "Personality on Social Network Sites"; Wilson, Fornasier, and White, "Psychological Predictors of Young Adults' Use of Social Networking Sites"; Zywica and Danowski, "The Faces of Facebookers."

50. Julia Gross and Lyn Leslie, "Learning 2.0: A Catalyst for Library Organizational Change," Electronic Library 28, no. 5 (2010): 657-68. 2012).

51. Sarah Steiner, "Strategic Planning for Social Media in Libraries" (London: Facet Publishing,

52. Ross et al., "Personality and Motivations Associated with Facebook Use."

53. Amanda Lenhart, "Adults and Social Network Web Sites," Pew Internet \& American Life Project report (2009), available online at www.pewinternet.org/Reports/2009/Adults-and-SocialNetwork-Websites.aspx [accessed 10 May 2013]; Rainie, "The State of Facebook: Slide Presentation during Facebook Fatigue: Fact or Fiction." 